\title{
FROM INTENT TO ACTION - A STUDY REGARDING HIGH SCHOOL STUDENTS' MOTIVATION IN CHOOSING A UNIVERSITY
}

\author{
Cristina-Veronica Partenie* \\ Bucharest University of Economic Studies, Bucharest, Romania, e-mail: parteniecristina@gmail.com
}

(Received: February 2019; Accepted: April 2019; Published: June 2019)

\begin{abstract}
In the context of an increasing competition among Romanian universities for attracting students, developing a strong brand that appeals to the stakeholders' needs and desires, while incorporating the institutions values and principles, is a desired course of action. A well-structured relatable brand enables future students to identify themselves with an institution and helps them in taking an important decision that could determine the outcome of their future. The present study analyses the factors that high school students consider when choosing to attend a certain university, through a quantitative research performed among 275 high school students from 33 high school institutions in Bucharest, Romania. Result helped classify the most important markers of a reputable university, which universities should consider when building branding programs. At the same time, universities' communication strategies should appeal to values that they share with their targeted audiences in order to increase their attractiveness.
\end{abstract}

Keywords: university branding, decision-making, student choice, higher education, marketing

JEL Codes: I230, M30, M370

\section{Introduction}

The Romanian higher education environment has been impacted in the past 30 years by numerous changes developed by the central authorities, and one major reorganization determined by the implementation of the Bologna process in 1999 (Brătianu, Pop, 2007). But despite a somehow unpredictable environment, one thing has remained constant: the desire of Romanian students to attend a higher education institution, although the main attracting universities have changed positions during the decades (technical studies, economics, medical studies or law).

${ }^{*}$ Corresponding author: Cristina-Veronica Partenie. E-mail: parteniecristina@gmail.com

Copyright (C 2019 The Author(s). Published by VGWU Press

This is an Open Access article distributed under the terms of the Creative Commons Attribution License - Non Commercial - NoDerivs License (http://creativecommons.org/licenses/by-nc-nd/3.0/) which permits unrestricted $\underline{\text { use, distribution, and reproduction in any medium, provided the original author and source are credited. }}$ 
Partenie, C.V., (2019)

From Intent to Action - A study regarding high school students' motivation in choosing a university

The preference for public higher education institution has remained constant in Romania, with only a few of private universities being well regarded. However, the number of public higher institutions has been on an ascending trend, with most of them having largely state funded tuitions. This has determined an increased competition among universities in order to attract potential students.

For most of the Romanian students, the decision to attend a university is taken long before the enrolment moment, sometimes in the early years of the high school period. As most Romanian high school students ultimately enrol in a higher education institution, their reasoning remains largely unexplored by researchers. The process though is often stressful (Whitehead, Raffan, Deaney, 2006) as it represents the first major decision that they take in their life and one that might have an important impact on their future career. Understanding the factors involved in making this decision is an important reference for higher education institutions in the process of drafting and transmitting recruitment messages to prospective students, but also in adapting to the expectations of its clients. This paper begins with a definition of the university brand and the identification of its purpose for organizations. Then, the factors described in the literature that influence the decision to choose a university are evaluated. The results of the study on the motivation of choosing a higher education institution developed among the pupils from several high schools in Bucharest are presented below. Finally, some recommendations are sent to universities to address factors considered important by potential students in deciding to enrol in a study program.

\section{Literature review}

\subsection{University branding}

In the context of an increasingly competitive education market, university branding has become a constant concern both for practitioners and for theoreticians (Curtis et al., 2009; Hemsley-Brown and Goonawardana, 2007; Naidoo et al., 2014; Stensaker, 2007; Vásquez et al., 2013). A somewhat natural consequence is the need for higher education institutions to present themselves through unique features appreciated by future students. As the survival of a university often depends on the perception of external stakeholders (including students) on the university brand, a better understanding of key stakeholders (students) and their perceptions of the university brand could help guide university marketing and brand managers develop more efficient recruitment materials, invest in advertising plans and overall branding efforts, including positioning the university brand on the global market.

Some researchers believe that branding can be applied in its classical terms to

18 Sciendo Studia Universitatis "Vasile Goldis" Arad. Economics Series Vol 29 Issue 2/2019 ISSN: 1584-2339; (online) ISSN: 2285 - 3065

Web: publicatii.uvvg.ro/index.php/studiaeconomia. Pages $17-32$ 
Partenie, C.V., (2019)

From Intent to Action - A study regarding high school students' motivation in choosing a university

higher education institutions (Opoku, et al., 2006), and classic branding functions are fully applied, while others view brands for higher education institutions as more complex and that conventional brand management techniques are inadequate for the sector, being borrowed from the private sector but not necessarily adapted to the characteristics of this market (Maringe, 2005). However, in the recent year's university branding as a research field has experienced a rise in the interest of researchers, with articles being published more frequently on the topic (Chapleo, 2015). The rationale of applying branding programs for higher education institution is the same as for any other organization: delivering a competitive advantage (DeCharnatony and McDonald, 2005). However, in the case of an institution as complex as a university, measuring its quality through its branding dimensions could discount on other important aspects (Jevons, 2006), and due to the fact, that "one has to take into account the needs of relevant linking departments that do not solely have commercially objectives" (Brookes, 2003, p.140).

A well communication branding program can support a consumer in its choice process, as considered by Blumenthal and Bergstrom (2003), generate awareness and recognition among its stakeholders (Chapleo, 2011) and ultimately help their prospective students in the decision-making process (Judson et al., 2006). In addition, universities wishing to create an image appreciated by future prospective students should understand the importance of several organizational and situational factors that can influence the image of universities (Kazoleas, et al., 2001). An analysis of the factors that influence the perceived image of a university can be a complex and complicated process, as they can be difficult to conceptualize and measure. For example, among academia a measurement of a university's quality of educational process is its ranking in one of the renowned university rankings (Davies and Chun, 2008), yet this is of little importance for potential students (Duesterhaus and Duesterhaus, 2014). Despite this difficulty, there are institutions that have mastered the art of branding, such as for example Harvard Business School. Dibb and Simkin (1993) claim that this is because they have managed to create a clear connection with their consumers. However, the discussion on what defines a successful university brand is by far to be concluded. Bunzel (2007) suggest that the evaluation of a successful university brand is the ranking of the institution in any international hierarchy, whereas Bulotaite (2003) considers success to be an "unique communicative identity".

To conclude, although progress has been made in the field of university branding, researches have still to agree on what are the main marketers of a successful university brand. In addition to this, the current theories must be considered at a local level, as special characteristics can apply. This has led the author to explore to what extend different elements influence the perception of a university's brand among Romanian high school students. 
Partenie, C.V., (2019)

From Intent to Action - A study regarding high school students' motivation in choosing a university

\subsection{Factors influencing students' decision-making process}

With an increased number of higher education institutions available, students' opportunities to enrol for a study program have increased, this making it more difficult for universities and colleges to access enough potential students and thus funding. This makes an effective and efficient communication across target audiences a mandatory endeavour. Understanding the rationale behind the decision-making process that high-school students undertake when selecting a university would enable a better pairing between student and institution (Pampaloni, 2010).

Faced with a potential life impacting decision, it is understandable that when deciding upon enrolling for a specific program, prospective students do not only that, but also make a commitment for an important period of their lives and careers. It is thus relatable that the decision-making process is a complex one. Different researchers have investigated this process, with various factors proving to be of importance: location (Wright and Kriewal, 1980; Welki and Navratil, 1987; Shank and Beasly, 1998), study program (Erdmann, 1983; Sevier, 1987; Mortimer, 1997; Connor, 1999, Voineagu, Pelău, Șerban, 2017), academic reputation (Murphy, 1981; Erdman, 1983; Litten and Hall, 1989; Morrow et al., 1995; Landrum et al., 1998) and employability (Murray et al., 1997). Ivy (2008) ranks seven different factors, from the most important to the least, that high school students consider when choosing a university: study program, reputation, tuition fees, engagement communication from the university, community interaction (academia, staff, students), promotion, and premiums (mixture of various offerings). Other studies have listed the student life and community activities (Pinar et al., 2011) as also playing an important role in the process. In addition to these, there are also interpersonal influences (Pampaloni, 2010) that need to be appraised when evaluating this process. Parents can have a greater influence on this decision as they are the adult figure held in the highest regard by students (Bergerson, 2009; Cabrera and LaNasa 2000; Helwig, 2004; Hossler et al., 1999; Ketterson and Blustein, 1997; Moogan, Baron and Harris, 1999; Otto, 2000; Paulsen, 1990; Rowan-Kenyon, Bell and Perna, 2008; Sachs, 2002; Scott and Daniel, 2001). Other possible influencers are professors (Franklin, 1995; Wasmer et al., 1997; Clarke and Brown, 1998), counsellors (Baker, 2002; Helwig, 2004; Johnson, 2000; Kelpe Kern 2000; Ketterson and Blustein, 1997; Mitchell, 1975) or even friends (Riggs and Lewis, 1990; Fuller et al., 1982; Franklin, 1995).

Perhaps most important to the actual ranking of the factors that the decision comprises of, is the actual purpose for deciding upon attending a university in the first place (Pampaloni, 2010): some students attend a certain program because of

20 sciendo Studia Universitatis "Vasile Goldis" Arad. Economics Series Vol 29 Issue 2/2019 ISSN: 1584-2339; (online) ISSN: 2285 - 3065

Web: publicatii.uvvg.ro/index.php/studiaeconomia. Pages $17-32$ 
Partenie, C.V., (2019)

From Intent to Action - A study regarding high school students' motivation in choosing a university

the career prospects that it offers, while others guide themselves by scholarships offerings or financial aids. Having such a vast value proposition to cover, it is important for universities to target their branding communications to specific audiences, in order to attract the correct category of students.

\section{Methodology and empirical data}

The purpose of the study was to identify the factors that drive the decision-making process for high school students when selecting what university to enrol for. In order to fulfil this purpose, three main objectives of were established:

- Determining what constitutes in the students' opinion the markers of a reputable university;

- Building a hierarchy of the factors that are important for high school students when choosing a certain university;

- Identifying the influencers that drive the decision-making process for students.

A questionnaire was applied on a cohort of 300 high school students from 33 high schools in Bucharest, Romania, and 255 valid responses were received. Age distribution among the respondents was: 6 students aged 15, 81 students aged 16, 172 students aged 17, and 16 students aged 18 . Students were asked to rate on a 5point Likert scale to what extend they agree with several statements (with 1 being ,strongly disagree" and 5 being „strongly agree”), the importance of various institutional characteristics, and persons who they might get advice from when selecting a university ( 1 being ,least important” and 5 being „most important”).

\section{Empirical results}

The current research has provided 255 valid responses that were analysed using SPSS Statistic Program to calculate the frequency distribution.

The most important aspect of a university that is considered by high school students when choosing a university is the employability rate after graduating. $61.1 \%$ of the respondents concluded that the most important aspect when choosing to enrol for a certain university are the perspectives of getting employed in that specific field. This result is good descriptor of the rationale of the decision-making process, as it shows that the main purpose of the Romania future students for attending a specific study program is its employability. 
Partenie, C.V., (2019)

From Intent to Action - A study regarding high school students' motivation in choosing a university

Table 1. The university offers me employment options after graduation

\begin{tabular}{|l|l|c|c|c|c|}
\hline \multicolumn{2}{|c|}{} & Frequency & Percent & Valid Percent & Cumulative Percent \\
\hline \multirow{4}{*}{ Valid } & strongly disagree & 4 & $1.5 \%$ & $1.5 \%$ & $1.5 \%$ \\
\cline { 2 - 6 } & mildly disagree & 8 & $2.9 \%$ & $2.9 \%$ & $4.4 \%$ \\
\cline { 2 - 6 } & neutral & 24 & $8.7 \%$ & $8.7 \%$ & $13.1 \%$ \\
\cline { 2 - 6 } & mildly agree & 71 & $25.8 \%$ & $25.8 \%$ & $38.9 \%$ \\
\cline { 2 - 6 } & strongly agree & 168 & $61.1 \%$ & $61.1 \%$ & $100.0 \%$ \\
\hline Total & 275 & $100.0 \%$ & $100.0 \%$ & \\
\hline Missing & 0 & $0.0 \%$ & & \\
\hline Total & 275 & $100.0 \%$ & & \\
\hline
\end{tabular}

Source: author's research

The above result is supported by the second and third most important factors regarded by the respondents as important in the decision-making process, which are: how knowledgeable is the institution with the latest findings in its field, and the fact that the university is able itself to generate knowledge and research.

Table 2. The university generates knowledge in its field

\begin{tabular}{|l|l|c|c|c|c|}
\hline \multicolumn{2}{|c|}{} & Frequency & Percent & Valid Percent & Cumulative Percent \\
\hline \multirow{4}{*}{ Valid } & strongly disagree & 1 & $0.4 \%$ & $0.4 \%$ & $0.4 \%$ \\
\cline { 2 - 6 } & mildly disagree & 3 & $1.1 \%$ & $1.1 \%$ & $1.5 \%$ \\
\cline { 2 - 6 } & neutral & 32 & $11.6 \%$ & $11.7 \%$ & $13.1 \%$ \\
\cline { 2 - 6 } & mildly agree & 99 & $36.0 \%$ & $36.1 \%$ & $49.3 \%$ \\
\cline { 2 - 6 } & strongly agree & 139 & $50.5 \%$ & $50.7 \%$ & $100.0 \%$ \\
\hline \multicolumn{2}{|l|}{ Total } & 274 & $99.6 \%$ & $100.0 \%$ & \\
\hline Missing & 1 & $0.4 \%$ & & \\
\hline \multicolumn{2}{|l|}{ Total } & 275 & $100.0 \%$ & & \\
\hline
\end{tabular}

Source: author's research

Table 3. The university is up to date with the latest findings in its field

\begin{tabular}{|l|l|c|c|c|c|}
\hline \multicolumn{2}{|c|}{} & Frequency & Percent & Valid Percent & Cumulative Percent \\
\hline \multirow{5}{*}{ Valid } & strongly disagree & 4 & $1.5 \%$ & $1.5 \%$ & $1.5 \%$ \\
\cline { 2 - 6 } & mildly disagree & 4 & $1.5 \%$ & $1.5 \%$ & $2.9 \%$ \\
\cline { 2 - 6 } & neutral & 28 & $10.2 \%$ & $10.2 \%$ & $13.1 \%$ \\
\cline { 2 - 6 } & mildly agree & 82 & $29.8 \%$ & $29.9 \%$ & $43.1 \%$ \\
\cline { 2 - 6 } & strongly agree & 156 & $56.7 \%$ & $56.9 \%$ & $100.0 \%$ \\
\hline \multicolumn{2}{|l|}{ Total } & 274 & $99.6 \%$ & $100.0 \%$ & \\
\hline \multicolumn{2}{|l|}{ Missing } & 1 & $0.4 \%$ & & \\
\hline \multicolumn{2}{|l|}{ Total } & 275 & $100.0 \%$ & & \\
\hline
\end{tabular}

Source: author's research 
Partenie, C.V., (2019)

From Intent to Action - A study regarding high school students' motivation in choosing a university

The emotional side of the decision-making process is visible in the fourth ranking aspect evaluated by $41.2 \%$ of the students as "important": the accordance between the university's values and their own. Both the percent of the result and the ranking on the measurement scale are relevant in this case and should be taken into consideration by universities when communicating to this audience.

Table 4. The university promotes values and principles that are similar to mine

\begin{tabular}{|l|l|c|c|c|c|}
\hline \multicolumn{2}{|c|}{} & Frequency & Percent & Valid Percent & Cumulative Percent \\
\hline \multirow{4}{*}{ Valid } & strongly disagree & 4 & $1.5 \%$ & $1.6 \%$ & $1.6 \%$ \\
\cline { 2 - 6 } & mildly disagree & 13 & $4.7 \%$ & $5.1 \%$ & $6.7 \%$ \\
\cline { 2 - 6 } & neutral & 38 & $13.8 \%$ & $14.9 \%$ & $21.6 \%$ \\
\cline { 2 - 6 } & mildly agree & 115 & $41.8 \%$ & $45.1 \%$ & $66.7 \%$ \\
\cline { 2 - 6 } & strongly agree & 105 & $38.2 \%$ & $41.2 \%$ & $107.8 \%$ \\
\hline \multicolumn{1}{|c|}{ Total } & 275 & $100.0 \%$ & $107.8 \%$ & \\
\hline \multicolumn{2}{|l|}{ Missing } & 0 & $0.0 \%$ & & \\
\hline \multicolumn{2}{|l|}{ Total } & 275 & $100.0 \%$ & & \\
\hline
\end{tabular}

Source: author's research

Although most sources would refer to international rankings when talking about reputation of a university, only $34.5 \%$ of the questioned students consider this as an important factor when choosing a certain university. However, it is important to mention that although ranking among the last most important factors, most of the respondents ranked it in the upper part of the measurement scale.

Table 5. The university ranks high in international hierarchies

\begin{tabular}{|l|l|c|c|c|c|}
\hline \multicolumn{2}{|c|}{} & Frequency & Percent & Valid Percent & Cumulative Percent \\
\hline \multirow{4}{*}{ Valid } & strongly disagree & 7 & $2.5 \%$ & $2.5 \%$ & $2.5 \%$ \\
\cline { 2 - 6 } & mildly disagree & 10 & $3.6 \%$ & $3.6 \%$ & $6.2 \%$ \\
\cline { 2 - 6 } & neutral & 72 & $26.2 \%$ & $26.2 \%$ & $32.4 \%$ \\
\cline { 2 - 6 } & mildly agree & 91 & $33.1 \%$ & $33.1 \%$ & $65.5 \%$ \\
\cline { 2 - 6 } & strongly agree & 95 & $34.5 \%$ & $34.5 \%$ & $100.0 \%$ \\
\hline Total & 275 & $100.0 \%$ & $100.0 \%$ & \\
\hline Missing & 0 & $0.0 \%$ & & \\
\hline \multicolumn{2}{|l|}{ Total } & 275 & $100.0 \%$ & & \\
\hline
\end{tabular}

Source: author's research

In choosing a university only $23.6 \%$ of the respondents consider the possibility to apply for an Erasmus scholarship when choosing a university. This could be explained by the fact that a large proportion of the respondents were not very accustomed with the topic and its implications. 
Partenie, C.V., (2019)

From Intent to Action - A study regarding high school students' motivation in choosing a university

Table 6. The university offers me the opportunity to apply for an Erasmus scholarship

\begin{tabular}{|l|l|c|c|c|c|}
\hline \multicolumn{2}{|c|}{} & Frequency & Percent & Valid Percent & Cumulative Percent \\
\hline \multirow{4}{*}{ Valid } & strongly disagree & 9 & $3.3 \%$ & $3.3 \%$ & $3.3 \%$ \\
\cline { 2 - 6 } & mildly disagree & 21 & $7.6 \%$ & $7.7 \%$ & $11.1 \%$ \\
\cline { 2 - 6 } & neutral & 79 & $28.7 \%$ & $29.2 \%$ & $40.2 \%$ \\
\cline { 2 - 6 } & mildly agree & 98 & $35.6 \%$ & $36.2 \%$ & $76.4 \%$ \\
\cline { 2 - 6 } & strongly agree & 64 & $23.3 \%$ & $23.6 \%$ & $100.0 \%$ \\
\hline Total & 271 & $98.5 \%$ & $100.0 \%$ & \\
\hline Missing & 4 & $1.5 \%$ & & \\
\hline Total & 275 & $100.0 \%$ & & \\
\hline
\end{tabular}

Source: author's research

When rating different elements that are regarded in the decision making-process, students once again validate previously provided answers. Thus, $57.4 \%$ of the students deem professors' skills in their field as the most important aspect when choosing a university.

Table 7. Professors' skills

\begin{tabular}{|l|l|c|c|c|c|}
\hline \multicolumn{2}{|c|}{} & Frequency & Percent & Valid Percent & Cumulative Percent \\
\hline \multirow{4}{*}{ Valid } & strongly disagree & 0 & $0.0 \%$ & $0.0 \%$ & $0.0 \%$ \\
\cline { 2 - 6 } & mildly disagree & 6 & $2.2 \%$ & $2.3 \%$ & $2.3 \%$ \\
\cline { 2 - 6 } & neutral & 18 & $6.5 \%$ & $6.8 \%$ & $9.1 \%$ \\
\cline { 2 - 6 } & mildly agree & 88 & $32.0 \%$ & $33.5 \%$ & $42.6 \%$ \\
\cline { 2 - 6 } & strongly agree & 151 & $54.9 \%$ & $57.4 \%$ & $100.0 \%$ \\
\hline \multicolumn{1}{|l|}{ Total } & 263 & $95.6 \%$ & $100.0 \%$ & \\
\hline \multicolumn{2}{l|l}{ Missing } & 12 & $4.4 \%$ & & \\
\hline \multicolumn{2}{|l|}{ Total } & 275 & $100.0 \%$ & & \\
\hline
\end{tabular}

Source: author's research

An important role when deciding is played by the facilities (students were invited to take into consideration libraries, dormitories, buildings or online available resources provided by the institution). Given the fact that most of the reputable higher education institutions in Romania were established more than 100 years ago, some of them experience difficulties in bringing the facilities up to date. One can notice however the students' aspiration to a more modern approach on the material side of studying. 
Partenie, C.V., (2019)

From Intent to Action - A study regarding high school students' motivation in choosing a university

Table 8. Facilities available at the university (ex. library, dormitories, building, online available resources)

\begin{tabular}{|l|l|c|c|c|c|}
\hline \multicolumn{2}{|c|}{} & Frequency & Percent & Valid Percent & Cumulative Percent \\
\hline \multirow{4}{*}{ Valid } & strongly disagree & 2 & $0.7 \%$ & $0.8 \%$ & $0.8 \%$ \\
\cline { 2 - 6 } & mildly disagree & 8 & $2.9 \%$ & $3.0 \%$ & $3.8 \%$ \\
\cline { 2 - 6 } & neutral & 22 & $8.0 \%$ & $8.4 \%$ & $12.2 \%$ \\
\cline { 2 - 6 } & mildly agree & 88 & $32.0 \%$ & $33.5 \%$ & $45.6 \%$ \\
\cline { 2 - 6 } & strongly agree & 143 & $52.0 \%$ & $54.4 \%$ & $100.0 \%$ \\
\hline \multicolumn{2}{|l|}{ Total } & 263 & $95.6 \%$ & $100.0 \%$ & \\
\hline \multicolumn{2}{|l|}{ Missing } & 12 & $4.4 \%$ & & \\
\hline \multicolumn{2}{|l|}{ Total } & 275 & $100.0 \%$ & & \\
\hline
\end{tabular}

Source: author's research

The entertainment possibilities and quality of student life rank third and fourth in importance for the respondents, with $44.1 \%$ and $45.6 \%$ considering it "important". When analysing these responses, however, it is important to note that as Bucharest is an important higher education centre in Romania and most of the respondents being local, they wouldn't have to consider a disruption in their social lives when moving to universities.

Table 9. Entertainment possibilities (ex. events organized for students, students' organizations)

\begin{tabular}{|l|l|c|c|c|c|}
\hline \multicolumn{2}{|c|}{} & Frequency & Percent & Valid Percent & Cumulative Percent \\
\hline \multirow{4}{*}{ Valid } & strongly disagree & 0 & $0.0 \%$ & $0.0 \%$ & $0.0 \%$ \\
\cline { 2 - 6 } & mildly disagree & 15 & $5.5 \%$ & $5.7 \%$ & $5.7 \%$ \\
\cline { 2 - 6 } & neutral & 51 & $18.5 \%$ & $19.4 \%$ & $25.1 \%$ \\
\cline { 2 - 6 } & mildly agree & 116 & $42.2 \%$ & $44.1 \%$ & $69.2 \%$ \\
\cline { 2 - 6 } & strongly agree & 81 & $29.5 \%$ & $30.8 \%$ & $100.0 \%$ \\
\hline \multicolumn{1}{|l|}{ Total } & 263 & $95.6 \%$ & $100.0 \%$ & \\
\hline \multicolumn{2}{|l|}{ Missing } & 12 & $4.4 \%$ & & \\
\hline \multicolumn{2}{|l|}{ Total } & 275 & $100.0 \%$ & & \\
\hline
\end{tabular}

Source: author's research 
Partenie, C.V., (2019)

From Intent to Action - A study regarding high school students' motivation in choosing a university

\begin{tabular}{|c|c|c|c|c|c|}
\hline \multicolumn{6}{|c|}{ Table 10. Quality of student life } \\
\hline & & Frequency & Percent & Valid Percent & Cumulative Percent \\
\hline \multirow{5}{*}{ Valid } & strongly disagree & 1 & $0.4 \%$ & $0.4 \%$ & $0.4 \%$ \\
\hline & mildly disagree & 1 & $0.4 \%$ & $0.4 \%$ & $0.8 \%$ \\
\hline & neutral & 43 & $15.6 \%$ & $16.5 \%$ & $17.2 \%$ \\
\hline & mildly agree & 119 & $43.3 \%$ & $45.6 \%$ & $62.8 \%$ \\
\hline & strongly agree & 97 & $35.3 \%$ & $37.2 \%$ & $100.0 \%$ \\
\hline \multicolumn{2}{|l|}{ Total } & 261 & $94.9 \%$ & $100.0 \%$ & \\
\hline \multicolumn{2}{|c|}{ Missing } & 14 & $5.1 \%$ & & \\
\hline \multicolumn{2}{|l|}{ Total } & 275 & $100.0 \%$ & & \\
\hline
\end{tabular}

Source: author's research

Lastly, although very important in other studies, the cost of attending a university is among the less important factors when choosing a university, as stated by the current study. This is explained by the preference of Romanian students for public higher education institutions, which are to a large extent state funded.

Table 11. Cost of attending a university

\begin{tabular}{|l|l|c|c|c|c|}
\hline \multicolumn{2}{|c|}{} & Frequency & Percent & Valid Percent & Cumulative Percent \\
\hline \multirow{4}{*}{ Valid } & strongly disagree & 10 & $3.6 \%$ & $3.8 \%$ & $3.8 \%$ \\
\cline { 2 - 6 } & mildly disagree & 21 & $7.6 \%$ & $8.0 \%$ & $11.8 \%$ \\
\cline { 2 - 6 } & neutral & 65 & $23.6 \%$ & $24.8 \%$ & $36.6 \%$ \\
\cline { 2 - 6 } & mildly agree & 88 & $32.0 \%$ & $33.6 \%$ & $70.2 \%$ \\
\cline { 2 - 6 } & strongly agree & 78 & $28.4 \%$ & $29.8 \%$ & $100.0 \%$ \\
\hline \multicolumn{2}{|l|}{ Total } & 262 & $95.3 \%$ & $100.0 \%$ & \\
\hline \multicolumn{2}{|l|}{ Missing } & 13 & $4.7 \%$ & & \\
\hline \multicolumn{2}{|l|}{ Total } & 275 & $100.0 \%$ & & \\
\hline
\end{tabular}

Source: author's research

When analysing possible influencers of the decision for attending a university one can observe that the questioned students rely more on their personal judgement, rather than on advice from other persons. Only 32.3\% percent of them would appreciate as important the role that esteemed teachers play in taking such a decision, with even less (27\%) looking upon their parents' opinion. Not only the adults' opinions are of little importance, but also the one of friends and acquittances, with $21.7 \%$ of students considering it "less important". 
Partenie, C.V., (2019)

From Intent to Action - A study regarding high school students' motivation in choosing a university

Table 12. Parents' influence

\begin{tabular}{|l|l|c|c|c|c|}
\hline \multicolumn{2}{|c|}{} & Frequency & Percent & Valid Percent & Cumulative Percent \\
\hline \multirow{5}{*}{ Valid } & not important & 23 & $8.4 \%$ & $8.7 \%$ & $8.7 \%$ \\
\cline { 2 - 6 } & less important & 34 & $12.4 \%$ & $12.9 \%$ & $21.7 \%$ \\
\cline { 2 - 6 } & so-so & 83 & $30.2 \%$ & $31.6 \%$ & $53.2 \%$ \\
\cline { 2 - 6 } & important & 71 & $25.8 \%$ & $27.0 \%$ & $80.2 \%$ \\
\cline { 2 - 6 } & very important & 52 & $18.9 \%$ & $19.8 \%$ & $100.0 \%$ \\
\hline \multicolumn{2}{|l|}{ Total } & 263 & $95.6 \%$ & $100.0 \%$ & \\
\hline \multicolumn{2}{|l|}{ Missing } & 12 & $4.4 \%$ & & \\
\hline \multicolumn{2}{|l|}{ Total } & 275 & $100.0 \%$ & & \\
\hline
\end{tabular}

Source: author's research

Table 13. Friends' or acquaintances' influence

\begin{tabular}{|l|l|c|c|c|c|}
\hline \multicolumn{2}{|c|}{} & Frequency & Percent & Valid Percent & Cumulative Percent \\
\hline \multirow{4}{*}{ Valid } & not important & 36 & $13.1 \%$ & $13.7 \%$ & $13.7 \%$ \\
\cline { 2 - 6 } & less important & 76 & $27.6 \%$ & $28.9 \%$ & $42.6 \%$ \\
\cline { 2 - 6 } & so-so & 83 & $30.2 \%$ & $31.6 \%$ & $74.1 \%$ \\
\cline { 2 - 6 } & important & 57 & $20.7 \%$ & $21.7 \%$ & $95.8 \%$ \\
\cline { 2 - 6 } & very important & 11 & $4.0 \%$ & $4.2 \%$ & $100.0 \%$ \\
\hline Total & 263 & $95.6 \%$ & $100.0 \%$ & \\
\hline \multicolumn{2}{|l|}{ Missing } & 12 & $4.4 \%$ & & \\
\hline \multicolumn{2}{|l|}{ Total } & 275 & $100.0 \%$ & & \\
\hline
\end{tabular}

Source: author's research

Table 14. Professors' influence

\begin{tabular}{|l|l|c|c|c|c|}
\hline \multicolumn{2}{|c|}{} & Frequency & Percent & Valid Percent & Cumulative Percent \\
\hline \multirow{5}{*}{ Valid } & not important & 29 & $10.5 \%$ & $11.0 \%$ & $11.0 \%$ \\
\cline { 2 - 6 } & less important & 32 & $11.6 \%$ & $12.2 \%$ & $23.2 \%$ \\
\cline { 2 - 6 } & so-so & 85 & $30.9 \%$ & $32.3 \%$ & $55.5 \%$ \\
\cline { 2 - 6 } & important & 85 & $30.9 \%$ & $32.3 \%$ & $87.8 \%$ \\
\cline { 2 - 6 } & very important & 32 & $11.6 \%$ & $12.2 \%$ & $100.0 \%$ \\
\hline \multicolumn{2}{|l|}{ Total } & 263 & $95.6 \%$ & $100.0 \%$ & \\
\hline \multicolumn{2}{l|l}{ Missing } & 12 & $4.4 \%$ & & \\
\hline \multicolumn{2}{|l|}{ Total } & 275 & $100.0 \%$ & & \\
\hline
\end{tabular}

Source: author's research

\section{Conclusions and further directions of research}

Faced with a decision that will affect their entire life, the questioned student have proven a sound reasoning, that values both rational factors (such as proven excellence in a field, quality of the act of teaching), but also appeals to their moral values, all with little influence from other persons.

Regarding the validation of the objectives of the study, several recommendations

$S$ sciendo Studia Universitatis "Vasile Goldis" Arad. Economics Series Vol 29 Issue 2/2019 
Partenie, C.V., (2019)

From Intent to Action - A study regarding high school students' motivation in choosing a university

could be done to universities, in order to better brand themselves to future students. Firstly, as students appreciate the employability rate of the study program, the universities could include in their branding program references to alumni, possible fields of employment, or examples of collaboration with different future employers. When enrolling for a study program, students envision their future career and practical examples could appeal to them and help them relate. The collaboration with different public or private institutions also support the validation of the second most important marker of a reputable institution, in the students' opinion: its ability to stay up to date with the most novel practices in the field.

In order for the students to develop a sense of belonging to a community, universities should organize open days. During such events, different facilities could be presented to the future students, combined at the same time with interactions, preferably in smaller groups to facilitate communication, with professors from the universities. As stated by them in the questionnaire, high school students seek knowledgeable future professors, and such events could help them engage with the academic staff of the institution. Of course, a practical implication needs to be also mentioned, namely that investments and development of the university's facilities have an impact also for future students, not only for the current ones or for the institution's staff. Lastly, more informal events, where high school students can interact with university students could help reveal the extend of the social lives that they could benefit for.

All the above should be included in the branding programs of the university, which should also include reference to values that the university holds in high regard; this will attract students that are compatible with such values. As the present study didn't explore the source from where high school students have gathered their information, this remains a potential future direction of research; this would enable universities to identify the best communication channels for reaching their target audiences.

\section{Acknowledgements}

The author thanks the anonymous reviewers and editor for their valuable contribution.

\section{Funding}

This research received no specific grant from any funding agency in the public, commercial, or not - for - profit sectors.

\section{Author Contributions}

The author conceived the study, carried out the literature review section and was responsible for the design, data collection, data analysis and interpretation. 
Partenie, C.V., (2019)

From Intent to Action - A study regarding high school students' motivation in choosing a university

\section{Disclosure Statement}

The author has no competing financial, professional, or personal interests from other parties.

\section{References}

1. Baker, H.E., (2002), Reducing adolescent career indecision: The ASVAB Career Exploration Program, Career Development Quarterly, 50, pp. 359-370

2. Bergerson, A.A., (2009), College choice as a comprehensive process, ASHE Higher Education Report, 35, pp. 21-46

3. Blumenthal, D. \& Bergstrom, A.J., (2003), Brand councils that care: towards the convergence of branding and corporate social responsibility, Journal of Brand Management, 10(4), pp. 327-341

4. Brătianu, C., Pop, N.A., (2007), Strategic university management and marketing, The Amfiteatrul Economic Journal, 9 (22), pp. 9-17

5. Brookes, M., (2003), Higher Education: Marketing in a Qausi-Commercial service industry, International Journal of Nonprofit and Voluntary Sector Marketing, 8(2), pp. 134-142

6. Bulotaite, N., (2003), University Heritage: An institutional tool for branding and marketing. Higher Education in Europe, XXVIII(4), pp. 449-454

7. Bunzel, D., (2007), Universities sell their brands, Journal of Product \& Brand Management, 16(2), pp. 152-153

8. Cabrera, A.F., LaNasa, S.M., (2000), Understanding the college-choice process. In A.F. Cabrera, S.M. LaNasa (Eds.), New directions for institutional research: Understanding the college choice of disadvantaged students (No. 107, pp. 5-22), San Francisco: Jossey-Bass

9. Chapleo, C., (2011), Branding a university: adding value or smoke and mirrors?, in Molesworth, M., Scullion, R. and Nixon, E. (Eds), The Marketisation of Higher Education and the Student as Consumer, Routledge, London, pp. 169-183

10. Chapleo, C., (2015), Brands in higher education: challenges and potential strategies, International Studies of Management \& Organization, 45(2), pp. 150163

11. Clarke, G., Brown, M.A., (1998), Consumer attitudes to higher education application process, Journal of Marketing for Higher Education, 8(4), pp. 83-96

12. Connor, M., Burton, R., Pearson, R., Pollard, E., Reagan, J., (1999), Making the right choice: how students choose universities and colleges-a survey of applicants, A report by the Institute for Employment Studies to CVCP, HEFCE and USCAS, pp. 1-75, London, Universities UK Publications

13. Curtis, T., Abratt, R., Mirror, W., (2009), Corporate brand management in higher education: the case of ERAU, Journal of Product \& Brand Management, 
Partenie, C.V., (2019)

From Intent to Action - A study regarding high school students' motivation in choosing a university

18(6), pp. 404-413

14. Davies, G., Chun, R, (2008), Projecting corporate character in the branding of business schools, in T.C. Melawar (Ed.), Facets of corporate identity, communication and reputation, Routledge, London, 2009, pp. 163-177

15. DeCharnatony, L., McDonald, M., (2005), Creating powerful brands, Oxford, UK: Elsevier

16. Dibbs, S., Simkin, L., (1993), The strength of branding and positioning in services. International Journal of Service Industry Management, 4(1), pp. 25-35

17. Duesterhaus, A.P., Duesterhaus, M., (2014), Attributes of successful university brands in the U.S.A., Journal of Brand Strategy, 3(2), pp. 169-183

18. Erdmann, D.G., (1983), An examination of factors influencing student choice in the college selection process, Journal of College Admissions, Summer, pp. 3-6

19. Franklin, M., (1995), The effects of differential college environments on academic learning and student perceptions of cognitive development, Research in Higher Education, 36, pp. 127-153

20. Fuller, C.W., Maski, F.C., Wise, A.D., (1982), New evidence on the economic determinants of post-secondary schooling choices, Journal of Human Resources, 17(4), pp. 477-498

21. Helwig, A.A., (2004), A ten-year longitudinal study of the career development of students: Summary findings. Journal of Counselling and Development: JCD, 82, pp. $49-57$

22. Hemsley-Brown, J., Goonawardana, S., (2007), Brand harmonization on the international higher education. Journal of Business Research, 60(9), pp. 942-948

23. Hossler, D., Schmit, J., Vesper, N., (1999), Going to college: How social, economic, and educational factors influence the decision students make, Baltimore, MD: Johns Hopkins University Press

24. Ivy, J., (2008), A new higher education marketing mix: the 7Ps for MBA marketing, International Journal of Educational Management, 22(4), pp. 288-299

25. Jevons, C., (2006), Universities: a prime example of branding gone wrong, Journal of Product \& Brand Management, 15(7), pp. 466-447

26. Johnson, L.S., (2000), The relevance of school to career: A study in student awareness, Journal of Career Development: JCD, 26, p. 263

27. Judson, K.M., Gorchels, L., Aurand, T.W., (2006), Building a university brand form within: a comparison of coaches' perspectives of internal branding, Journal of Marketing for Higher Education, 16(1), pp. 97-114

28. Kazoleas, D., Kim, Y., Moffit, M.A., (2001), Institutional image: A case study, Corporate Communication: An International Journal, 6, pp. 205-2016

29. Kelpe Kern, C.W., (2000), College choice influences: Urban high school students respond, Community College Journal of Research \& Practice, 24, pp. 487494

30 Sciendo Studia Universitatis "Vasile Goldis" Arad. Economics Series Vol 29 Issue 2/2019 ISSN: 1584-2339; (online) ISSN: 2285 - 3065

Web: publicatii.uvvg.ro/index.php/studiaeconomia. Pages $17-32$ 
Partenie, C.V., (2019)

From Intent to Action - A study regarding high school students' motivation in choosing a university

30. Ketterson, T.U., Blustein, D.L., (1997), Attachment relationships and the career exploration process, Career Development Quarterly, 46, pp. 167-178

31. Landrum, E.R., Turrisi, R., Harless, C., (1998), University image: the benefits of assessment and modeling, Journal of Marketing for Higher Education, 9(1), pp. 53-68

32. Litten, L.H., Hall, A.E., (1989), In the eyes of our beholders: some evidence on how high-school students and their parents view quality in colleges, Journal of Higher Education, 60(3), pp. 302-324

33. Maringe, F., (2005), Interogating the crisis in higher education marketing: the CORD model, International Journal of Higher Education Management, 19(7), pp. 564-578

34. Mittchel, A.M., (1975), Emerging career guidance competencies, Personnel and Guidance Journal, 53, pp. 700-703

35. Moogan, Y.J., Baron, S., Harris, K., (1999), Decision-making behavior of potential higher education students, Higher Education Quarterly, 53, pp. 211-228

36. Morrow, M.J., Doyle, K., Ogletree, R.J., Parsons, N.P., (1995), Adult learners in undergraduate health education, professional education programmes: planning for now and the future, Journal of Health Education, 26(6), pp. 333-337

37. Mortimer, K., (1997), Recruiting overseas undergraduate students: are their information requirements being satisfied? Higher Education Quarterly, 51(3), pp. 225-238

38. Murphy, P.E., (1981), Consumer buying roles in college choice: a three phase model and the implications for policy makers, College and University, 56(2), pp. 140-150

39. Murray, J., Murray, R., Lann, L., (1997), Growth strategies for U.S. colleges and universities, Journal of Marketing for Higher Education, 8(1), pp. 41-53

40. Naidoo, R., Pringle, J., (2014), Branding business schools: academic struggles with the management of reputation, in Pettigrew, A.M., Cornuell, E. and Hommell, U. (Eds), The Institutional Development of Business Schools, Oxford University Press, Oxford, pp. 176-195

41. Opoku, R.A., Hultman, M., Saheli-Sangari, E., (2008), Positioning in market space: The evaluation of Swedish universities' online brand personalities, Journal of Marketing for Higher Education, 18(1), pp. 124-144

42. Otto, L.B., (2000), Youth perspectives on parental career influence, Journal of Career Development, 27, pp. 111-118

43. Pampaloni, A., (2010), The influence of organizational image on college selection: what students seek in institutions of higher education, Journal of Marketing for Higher Education, 20(1), pp. 19-48

44. Paulsen, M.B., (1990), College choice: Understanding student enrollment behavior, ASHE-ERIC Higher Education Report, No. 6., Washington DC: The 
Partenie, C.V., (2019)

From Intent to Action - A study regarding high school students' motivation in choosing a university

George Washington University, School of Education and Human Development

45. Pinar, M., Trapp, P., Girard, T., Boyt, T., (2011), Utilizing brand ecosystems for branding and building brand equity in higher education, International Journal of Education Management, 25(7), pp. 724-739

46. Riggs, R.O., Lewis, W.L., (1980), Applicability or marketing research to student recruitment, Journal of College Student Personnel, 21, pp. 467-468

47. Rowan-Kenyon, H.T., Bell, A.D., Perna, L.W., (2008), Contextual influences on parental involvement in college going: variations by social class, Journal for Higher Education, 79, pp. 564-586

48. Sachs, S.B., (2002), Voices of reason: Adolescents talk about their futures over time, Westport CT: Bergin \& Garvey

49. Scott, R., Daniel, B.V., (2001), Why parents of undergraduates matter to higher education, New Directions for Student Services, 94, pp. 83-89

50. Sevier, R., (1987), How students choose a college, Currents, 13, pp. 145-152

51. Shank, M.D., Beasley, F., (1998), Gender effects on the university selection process, Journal of Marketing for Higher Education, 8(3), pp. 63-71

52. Stensaker, B., (2007), The relationship between branding and organizational change, Higher Education Management and Policy, 19(1), pp. 1-17

53. Vásquez, C., Sergi, V., Cordelier, B., (2013), From being branded to doing branding: studying representation practices from a communication-centered approach, Scandinavian Journal of Management, 29(2), pp. 135-146

54. Voineagu, V., Pelău, C., Șerban, D., (2017), Research Regarding the Correlations Among Factors Influencing the Satisfaction of Students in an University, Economic Computation and Econonomic Cybernetics Studies and Researhch, 51(2), pp. 55-66

55. Wasmer, D.J., Williams, J.R., Stevenson, J., (1997), A re-conceptualization of the marketing mix: using the $4 \mathrm{C}$ 's to improve marketing planning in higher education, Journal of Marketing for Higher Education, 8(2), pp. 29-35

56. Welki, A.M., Navratil, F.J., (1987), The role of applicants' perceptions in the choice of a college, College and University, 62(2), pp. 146-160

57. Whitehead, J.M, Raffan, J., Deaney, R., (2006), University choice: What influences the decision of academically successful post-16 students? Higher Education Quarterly, 60, pp. 4-26

58. Wright, P., Kriewal, M.A., (1980), State-of-mind effects on the accuracy with which utility functions predict marketplace choice, Journal of Marketing Research, 17, pp. $277-293$ 